\title{
¡Ah de la casa!
}

\author{
A Santiago Fuentes y M. ${ }^{a}$ Teresa Escribano
}

I

\section{REVELACIÓN DE DIOS EN LA NATURALEZA}

¡Ah de la casa! ¿Hay alguien?

¿Nadie me responde?

No preguntes, que está deshabitada, me dicen muchos hombres buenos que exploran $\mathrm{y} \cdot$ miden y analizan sus estancias.

II

\section{EL DESENCANTAMIENTO DEL MUNDO}

Cananeos, fenicios, jebuseos, egipcios, israelitas, pigmeos, papúes, guanches, quechuas, wikingos, kurdos, tártaros, aztecas, musulmanes, hindúes, guaraníes, mongoles, aimaras, griegos, fueguinos, sardos, manchúes, nipones, cretenses, europeos de antes del Siglo de las Luces..., despavoridos, sintieron a Dios en la tormenta, su voz de cólera rompiendo en truenos y en rayos el fulgor de su mirada. 
Dios no está en la tormenta, no hay voces ni miradas; tan sólo un fluir eléctrico de carga y descarga.

Nada transparenta, de nadie es huella

ni símbolo de nada:

puro acaecer mundano, aquí empieza y se acaba.

Dios no está en la tormenta, ni en la lluvia, cuando extiende mansamente sus cortinas por el

ni en el sol, que da vida, [campo, ni en el volcán, que trae la muerte, ni en el temblor de tierra, que amedrenta.

No hay mensajes cifrados; nadie nos habla desde fuera.

Dios no está en la tormenta, ni en el rostro azul de la mañana, ni en la rosa encendida, ni en el fuego y cendal de la granada (¡ay, mi san Juan de la Cruz!; ¡ay, mi Fr. Luis de Granada!), ni en las hogueras que el otoño enciende como cantos de amor para la muerte. Son realidad, no sombra; blanco y no flechas.

Dios no está en la tormenta, ni en la brisa que estremece los allozos, ni en las brasas del poniente, que se apaga, ni en la risa del agua, ni en la espiga que cuaja, ni en los nunca contados ojos con que nos mira la noche, asombrada. De nadie son voceros ni vestigios de nada. 
III

\section{INTERPRETACIÓN Y VERDAD}

Las cosas no hablan.

$\mathrm{Su}$ voz es nuestra voz; su rostro, nuestro rostro.

Se visten como las vestimos; su nombre, el que les damos.

Les dictamos el peso, medida y ritmo para su baile, hechura de nuestros sueños.

Varían cuando variamos

y se paran, si nos paramos, se paran.

Según somos nosotros, así son ellas.

La verdad no está ahí, oculta entre celajes, esperando

que un amante encelado la desnude.

Ni huye de árbol en árbol

esquivando, burlona, al buscador, desalentado.

$\mathrm{Ni}$ es el centro de una circunferencia

desmesurada, cósmica,

cuyos puntos,

equidistantes,

seríamos nosotros

para que no sea tuya ni mía, sino nuestra.

$\mathrm{Ni}$ es una antorcha que nos ilumina

y nos dice:

aquí estoy;

esto es justo, esto es bueno, esto es bello.

La verdad se hace, la creamos.

Salta, a veces,

cuando el ojo bruñido de la mente

palpa la realidad en sus entrañas,

como saltan las chispas

del pedernal del eslabón herido.

El hombre que escudriña tras la prensil mirada es quien da forma al rayo que recibe

y lo traduce en fórmulas y lo vierte en palabras.

Es él quien pregunta y él es quien responde;

quien codifica los datos en señales

y quien compone el texto que después creemos

obra de la naturaleza. 
Pero el hombre que investiga ¿quién es?

Es él y en él los otros:

un eslabón complejo

de una larga cadena de aciertos y de errores.

Selvas, bacterias, insectos, alimañas,

aves, estrellas, árboles y rocas

han entrado en el río de su vida

y bullen en la soalma.

Hombres de ayer y hoy en él alientan,

y hombres del futuro

en él cobran ya rostro y existencia.

Vivir es tender hacia el mañana

y es la memoria atesorada

de todo lo que ha sido,

aquí y ahora encarnada

en libertad.

La verdad se hace, la hacemos, la creamos en comunal empresa de esfuerzos solidarios:

la verdad es nuestra.

Y quien logra apresarla en la red de una fórmula, no la guarde.

La verdad clandestina se hace estéril,

palidece y se muere.

Grítela «desde lo alto del tejado», vocéela en la plaza,

a mediodía y a los cuatro vientos;

que la oigan los sordos y la vean los ciegos.

Sólo cuando, sembrada, fructifica

$y$ es vida en otras vidas,

es Verdad la verdad,

porque entonces es nuestra. 
IV

\section{HISTORIA}

Hombres hubo que adoraron los montes, los árboles, las nubes, el toro y la serpiente, el fuego, las estrellas y los ríos, porque les eran dioses, dueños de poderes sobrehumanos, a los que era menester tener siempre propicios.

Un paso más y árboles, estrellas y ríos dejaron de ser dioses.

Sólo eran ya la voz de Dios, imagen de su rostro, que en ellos se pintaba

y hablaba por ellos a los hombres.

Dios estaba en ellos, presente, vivo, actuante, única fuerza verdadera que movía el mundo y sus partes, y a los hombres daba éxito (o fracaso, ausentándose).

Y así lo percibían: tangible en las lanzas victoriosas - ¡evohé, «el día de Yahvé»!y en el rayo de sol que abrasa el campo.

Lo veían en la tienda del cielo luminoso y en la noche profunda de ojos parpadeantes. El trueno era su voz, sus caballos el viento. Se anunciaba en la brisa y en las mieses ondulantes cantaba su canto de alegría.

Como se ve el paisaje en el espejo limpio de las aguas o a través del cristal de la ventana; como se lee un texto escrito en lengua conocida, sin esfuerzo ni trancos de razones, limpia y tersamente 
sentían el aliento de Dios en la pradera,

y escuchaban su voz huracanada

o suave como brisa,

y leían por menudo su mensaje

en el inmenso libro de la naturaleza.

Un buen día se fue Odín, el vidente, soberano de dioses, y con él se fue Tir, el Marte de las sagas, el que perdió una mano en la boca del lo-

[bo,

el jurista taimado,

fundador del derecho, armadijo de incautos.

Y se fue Zeus-Júpiter

con su carro alado y sus caballos tonantes,

salvador, señor del universo,

celador de la ley,

aunque rijoso y trastulo en demasía.

Se fue también Yahvé,

el que hendía los montes con el rayo

y huracanaba con su voz los robles.

y Elohim,

quiñonero de pueblos,

el que dio Israel a Yahvé como lote de heredad. (Dt 32,8-9)

Se fueron Aitor y Jaungoikoa,

señores de recios aizcolaris y esforzados remeros,

y Quetzalcóatl y el Sol, adorado en Machu Piechu.

Como se van las sombras al venir el alba, como huye el pájaro de la jaula que el descuido dejó abierta, así se fueron ellos (y otros muchos, que la historia es larga), golosos todos

de sangre, incienso y vírgenes,

dejando en desamparo,

al raso,

el alma de sus fieles.

«Últimamente, en nuestros mismos días», se ha ido Dios, evaporado,

el Dios de nuestros padres, nuestro Dios.

« ¿Dios ha muerto!». 
¡Dios ha muerto! Y con su muerte se han cuarteado nuestras esperanzas y nuestra fe anda herida.

Como el árbol partido por el rayo, denegrido, al que una tormenta persistente socava las raíces, así están nuestras almas, mirando con espanto cómo avanza la muerte, precedida de la angustia, seguida de la nada.

¡Dios ha muerto! ¿Ha muerto nuestro Dios, ¿Viva Dios!, o Dios ha muerto?

El hombre de razón creía, ¡iluso!, que era dueño del mundo.

Un poco de tiempo, no más, y las cosas le entregarían rendidas sus secretos.

Hasta el cogollo mismo la razón matemática entraría

y las pondría al descubierto, claras como la luz del día: esto hay, nada más; todo explorado y visto.

Pero la realidad ha resultado esquiva; se escapa de nuestras redes, huye de nuestra vista y no hay razón que le dé alcance.

La claridad total es un fantasma, no distinto de aquel que al hombre primitivo, le llevaba a poner su cuenco de comida al árbol que velaba por la tribu.

Mas algo hemos cogido en la aventura.

Dios no está en la tormenta, icierto!, ni en la quejumbre de la fuente, ni en la timidez del gamo, que es su defensa, ni en el afán de las hormigas buscando provisiones. Ni labra en el gusano túnicas de seda ni enloquece al cerezo en primavera. Materia y energía: eso es todo. 
Dios no está en la tormenta.

Quienes afirman lo contrario

responden con razones antes hechas, repetidas sin sentido, de memoria.

$\mathrm{Ni}$ ellos creen ya en ellas.

Son palabras rutinarias

que aprendieron en libros que ya no cuentan.

Al llegar la tormenta,

ya no «treme la tierra ni la gente se humilla».

Se acoge al pararrayos,

no a santa Bárbara,

ni enciende votivas velas benditas.

Ya no se hacen rogativas,

sino pantanos y canales.

Se trabajan las semillas

y está en plena faena la genética.

Es el hombre el que establece el orden, el que fija normas'y señala reglas.

\section{V \\ CONTEMPLACIÓN Y CONOCIMIENTO}

Que el teso con sus mieses nos embriague.

Gocemos de la luz, goce la carne entera.

Que el manantial umbrío

se entre por nuestros poros y nos llene

de su frescor sabroso

y nos esponje, haciéndonos sensibles

a los mil y un estímulos de fuera.

¡La gracia alabeada de las ramas

cargadas con sus frutos;

la magia de la brisa en la alameda;

el silencio infinito de las noches

alumbradas de estrellas;

el aire cristalino de las cumbres;

el frenesí del ruiseñor en éxtasis;

el aroma encabezado del campo,

cuando lo exalta primavera! 
Gocemos, sí, gocemos el paisaje

sin hacer de él pretexto

para ver a su trasluz lo que no vemos.

Depuesta la razón, fundámonos con él en un abrazo de identidad.

Sea él nuestro espejo, símbolo del alma y sus anhelos, espejo aclarador de los estados interiores, paisajes más profundos, ya alegres, ya sombríos.

Y dejemos que el ímpetu se alce a cumbres más radiantes, cencidas,

por nadie aún pisadas.

Que sobrepase el hombre al hombre y, de inmensidad iluminados, soñemos con una luz inviolada;

una luz que es belleza, la luz de verdad;

una luz no creada, no tocada por mano de hombre;

una luz que es amor,

casa que nos cobija, aire que nos da vida, pan que nos alimen-

¿Prohibido soñar?

[ta, agua que nos alivia.

¿Serán tan sólo «sueños de soñadores», que sueñan por soñar?

Exploremos la tierra y las galaxias;

sometámoslo todo a la razón.

Que ni un palmo quede

sin el roce del tentáculo de la indagación.

Entremos en la secreta tracería de las diminutas moléculas;

desvelemos el secreto del genoma;

separemos los genes;

reformemos la herencia deformada. iAh, el ADN y el ARN!

La delicia de explorar mundos siempre nuevos

nos invada,

dulcísima marea,

y nos lleve mar adentro, a suelos no vislumbrados,

imposibles de soñar.

Mas las últimas preguntas,

las que golpean insistentes en nuestro corazón, se quedan sin respuesta. 
No se reciben datos y sin ellos

es inútil que intentemos elaborar textos

apócrifos,

haciéndonos trampas a nosotros mismos.

Los caminos se borran, el misterio no habla, no hay huellas.

Las preguntas se quedan en el aire.

Como si una cámara invisible

fijara la boca que va en busca del beso,

mientras el rostro amigo

se difumina en la borrosa cabellera de una niebla impenetrable.

En la niebla, Dios se pierde a lo lejos,

presentido.

¿Dios

o el agujero negro del espanto,

que engullirá nuestra energía transformándola?

\section{VI}

\section{LA FE}

Las últimas preguntas se quedan sin respuesta.

El que horadó el misterio, el Unigénito, el Hijo del agrado, el que vive para siempre y está junto a Dios, «él es la explicación».

Los que fueron testigos del milagro, los que «vieron y oyeron y palparon la Vida», porque la Vida se hizo carne entre ellos y los transfiguró, nos lo han anunciado para que con ellos compartamos la Vida, que es amor.

El amor que responde al amor recibido, el amor que se pierde porque vivan los otros, el amor que se tiene en pie hasta la muerte, esa es la vida eterna, que dura para siempre, porque mana de Dios y en Dios desemboca: «ahí vive Dios». 
Ya tenemos un dato sometido a experiencia.

Sólo él nos permite hablar sobre Dios, volvernos hacia el mundo, celebrar su existencia como obra divina, convertirlo en palabra que cante a la Palabra que lo hizo, encontrarle sentido, gritar que todo en él está llamando a Dios.

Mas no olvidemos nunca, somos olvidadizos, el punto de partida; el que nos empuja y el que nos mantiene en nuestra reflexión; el único que da autenticidad a nuestro texto sobre Dios: el amor, que se entrega hasta la muerte por amor.

Sin él, nuestro texto se vuelve algarabía, hijo de nuestros fantasmas, blasfemia contra Dios.

«Levántate, ¡oh Dios!, defiende tu causa»

de los que pronunciamos tu santo nombre en vano;

restablece tu gloria entre nosotros;

limpia nuestra mirada;

arranca nuestras máscaras;

ahuyenta nuestros fantasmas, las ideas-ídolo que nos forjamos sobre ti.

Líbranos, ¡oh Dios!, de nosotros mismos.

Desde la Palabra, una y otra vez, incansables,

busquemos la palabra

precisa,

la justa, la adecuada,

la nuestra,

la que llegue al corazón de los hombres, brotada de nuestro corazón.

Y si la vida, renovada, la borra, escribamos de nuevo un nuevo texto:

así los niños rehacen afanosos

los castillos de arena que el mar, imperturbable, les deshace. 